\title{
ЕЛЕМЕНТИ БОЖИЋНЕ ОБРЕДНЕ ПРАКСЕ КОД ПОМОРИШКИХ СРБА У РУМУНИЈИ
}

\begin{abstract}
Рад је настао на основу теренских истраживања које сам обавио ове године у појединим селима у долини Мориша а где још постоји србска заједница и где сам пронашао казиваче упућене у упражњавање црквено-народних обичаја. У раду су наведени елементи божићне обредне праксе који се још практикују као и поједине обредне радње које су се у међувремену изгубиле и данас се више не врше. Истовремено покушали смо да одгонетнемо и разлоге које су допринели заборављању или губљењу ових божићних обичаја код породица поморишких Срба.
\end{abstract}

Кључне речи: Срби у Поморишју, Божић, чесница, бадњак, коринђа, положник.

Теренска истраживања која сам обавио ове године у Поморишким селима Наћфала, Варјаш, Саравола, Печка, Чанад, Кетфељ, део су пројекта Истраживање историје и културе Срба у Румунији, који организује Центар за научна истраживања и културу Срба у Румунији, при Савезу Срба у Румунији. ${ }^{2}$

\section{1.}

Иако је празник Христовог Васкрсења, у богословском смислу, Празник над празницима, ипак празник Рођења Христовог или Божић обилује разноврсношћу и лепотом обичаја како оних који претходе овом празнику,

\footnotetext{
${ }^{1}$ avasrb@yahoo.com

${ }^{2}$ Казивачи из Наћфале су сво троје рођени у Наћфали: Светислав Петков рођен 13. маја 1944. год.; Слободанка Петков рођ. Галетин, рођ. 20. фебр. 1951. год.; Дејан Петков рођен 18. марта 1942. године. Свима њима најискреније благодарим за сву помоћ и пружену подршку.

За Кетфељ сам користио своје личне белешке записане на основу казивања моје баке Анђелке Чоботин рођене августа 1920. год., потом Велинке Савић као и казивања Слободана Јовичин. Свештеници Огњан Плавшић, Радослав Стојков и Петар Пера Илијевић говорили су о старим обичајима из Сараволе и Чанада.

О обичајима из Варјаша говорили су Милица-Мица Цвејић рођена 01. маја 1942. и Драган Илин.

Божићне обичаје из Печке описао је свештеник Милован Милин и Бојана Милован рођена 1939. год.
} 
тако оних у току тродневног празновања, као и обичајима који се још одржавају у периоду после Божића. Како то лепо наглашава Милина Ивановић Баришић ,...божићни празници могу се посматрати неком врстом нулте тачке почетка у кружном годишњем кретању и празновању". ${ }^{3}$ Најважнији елементи божићне обредне праксе код Поморишких Срба везани су за Бадњи дан и подразумевају: увођење положника, бадњу вечеру, уношење Божића, обредне колаче, коринђање; а на сам дан Божића: јутарње умивање, идење у цркву, божићни ручак као обичаје који се још увек одржавају.

\section{2.}

Бадњи дан. Последњи дан Божићног поста, дан уочи самог празника Христовог Рођења, испуњен је припремама за велики празник. Раније су, веома рано изјутра, домаћице устајале да замесе квасац за све божићне обредне хлебове. Домаћини су чистили двориште, штале, спремали храну за стоку, за живину да би имали сва три дана Божића, спремали су дрва за ложење а домаћице вршиле последња спремања по кући. Сва три дана празника у кући и домаћинству није се ништа радило. Данас су веома ретка домаћинства у којиме се то још ради. Један од важних елемента у раним јутарњим сатима било је дочекивање положника.

Положник. Према казивању мојих саговорника сви знају за положника, чак су неки и својевремено имали ову улогу.

ЧАНАД: (Ко је био положник? Да ли је постојао положник?) Jecme. Углавном је то био мушкараи који је долазио у кућу. Углавном деца су била. Они су волели то јер су добијали леје. Знам да су старије жене, мајка, углавном је узимала жита и кукуруза и сипала му на главу и викала пилиће, пи,пи,пи,...онда говорила мууу...и тако како праву животиње.

ВАРЈАШ: Први мушки који упадне у кућу тај је био положник. Домаћицуа га посади на столииу, да седу квочке и на главу му посипа помешано жита и кукуруза. (У чему је држала ово зрневље?) Све је то било већ спремно у једну уплетену котарииу и одавде је узимала. (А да ли је нешто говорила док је положника посипала зрневљем?) Па да. Говорила је тако као кад виче пилиће, гуске, пи,пи, ли, ли, а правила је и као кад рже коњ или кад риче крава. (А положника да ли су нечим наградили, платили?) Раније, кад сам била дете давали су и од омршаја, а после леј. Сви су се радовали кад добију леј.

НА ФФАЛА: Код нас положник је био дете из куће. Мати или баба посаде дете на врећу а негде и на столичищу и ондак на глави му сипаду зрюе

\footnotetext{
${ }^{3}$ Милина Ивановић Баришић. Божић код Срба у Румунији - Краљевац и Чанад. Исходишта 5, Темишвар - Ниш, 2019, 130.
} 
од кукуруза и жита. (У чему су то зрневље држали?) Наши су имали у сито, y решето. (А за сво то време ћуте и ништа не говоре, или нешто кажу?) Па не кажу ништа само праву као краве, као коњи: мууу, ихохо и као пилићи: пи,пи и тако. То каже и она жена а треба и положник да каже да би се јагњиле овце, да би било пилића, да би била родна година. (А положника чиме су награђивали? Чиме?) Па углавном новцима, јер су се новцу сви радовали. А давали су и ораје и јабуке.

Занимљиво је да ни у једном истраженом месту нисам наишао на један стари србски обичај, на који се присетила моја казивачица, а који је некада у Наћфалу био уобичајен. Ради се, наиме, о животињском положнику за који моја саговорница каже: Има неки који су у кућу донели кокошку, гуску или овиу да буде положник. Увођење у кућу таквог животињског териоморфног положника распрострањено је било, углавном, у јужном Банату где су уводили јагње, овцу или теле пошто су то мирне и кротке животиње. ${ }^{4}$ Чајкановић говори о териоморфном положнику, о божанској животињи као о старинском тотему. ${ }^{5}$

ПЕЧКА: Код нас и у Арад Гај, па и у Надлак и Торғу ми смо га звали положајник. За положајника је сматран први посетилач који је честитао Бадюи дан. Долазио је у кућу рано ујутро, дечак, младић или неко друго муико лиие из суседства. Он је улазио и честитао празник а домаћини би га наздравили и благодарили на посету и честитке. (Да ли су домаћини или положник опонашали кокошке и животиње?) He. Huје се то радило. (А награда положника која је била?) Ако су деца онда воћем, јабукама, крушкама, а ако је одрасла особа онда чаша ракије или вина.

КЕТФЕљ: Изјутра се дочекивао положник како се већ називала особа која је прва долазила у кућу.

У домаћинствима где су била деца, обично су њих будили како би они, као деца, имали улогу положника. Дете је било постављено да седне на једну врећу која је била прострвена на поду. У неким домаћинствима положник је био постављен на земљу, односно на под собе. Домаћица је у једној посуди имала, већ спремно зрневље помешаних житарица, углавном жита и кукуруза и полако једном руком узимала и сипала детету на главу, дозивајући, при том, живину, гуске, патке, свиње, краве, коње. Исте овакве ономатопеје као: пи пи пи, ли ли ли, гусу, гусу, ихохо, мууу; изговарао је и положник. Уколико је дете било из куће, награђен је новцем.

Божићни колачи и обредни хлебови. Јаворка Марков Јоргован записује да су „за Божић домаћице месиле велики божићни колач, колачиће

\footnotetext{
${ }^{4}$ Босић Мила. Божићни обичаји Срба у Војводини. Нови Сад: Музеј Војводине, 76.

${ }_{5}^{5}$ Чајкановић Веселин. Неколике примедбе уз српски Бадњи дан и Божић. Студије из Срnске религије и болклора 1910-1924. Београд 1994, 150.
} 
за коринђаше, здравље, сунце и месец, волове у јарму, авлију са живином, сламом и кукурузовином, чесницу."6

ЧАНАД: У нашу кућу се месило здравље. Мама га је намазала медом одозгоре. А колач уплетен. (Да ли се у њему мећало оре или стручак босиљка везан са црвеном вуницом?) Код нас је без орета или босиљка. У колач се забадала свећа а на први дан Божића се резао. (Како се то радило и ко је то радио?) Газда је кидао на комаде и свима давао да једу.

ВАРЈАШ: На Бадюи дан изјутра меси се Божићни колач са јајима и мете се и шећера да буде слађи. Као прави колач. (Да ли се плете?) Како да не. Замеси се велики, округал. Одозгоре се уплете у 3. или 4. струке а около се увије плетеница од 2. струке. Убоду се и четири руже од теста около и једну у средину У сваку ружу се мете по једно оре а у ону ружу са средине се убоде струк босиљка везан са ирвеном вуном... Да би био леп и светао одозго се намаже са жуманием од јаја. Овај колач тата је мето у сито или решето и стојало је настал.

(А здравље да ли се месило?) Јесте. Како да не. Здравље се месило од истог теста као и колач. Се постави у плек у четир ћошка, одозгоре се присеку 3-4. реза и намаже се јајима, као и колач.

(Чесница да ли се правила?) Боже мој, па како. Како Божић без чесницее? На први дан Божића, домаћица устане рано замеси тесто, брашно, со, вода и почиње да га растеже колико је астал велики. Велика обга се сложи у плек у пет, шест листова филована са самлевеним орасима, шећером и сувим грожђем. Наслажу се тако 4. до 5. обге. (Па то је доста дебело.) Дабоме. А кад је печено и извуче се из рерне онда се намаже са медом. (А леја нема?) Има, како нема, сакрије се негде међ ове листове. А може и два леја. Зависи.

НАЋФАЛА: Меси се велики колач. Тај колач се реже после ручка, на први дан Божића, кад се дође из иркве. Прво се доњи део три пута прекрсти ножом ондак, обично су била два детета, а колач се пресече на 4. дела, а на среди се сипа мало вина, онако унакрст, једно код другог.

(Да ли се још нешто меси?) Па меси се здравље. Наши стари су намазали горњу страну сас медом да нам здравље буде слатко као мед. (И кад се здравље начињало и јело?) Па јели смо га на Бадюе вече на вечеру. Сви су требали да једу свако своје парче. Знам, код нас, кад се начињо ондак смо неколико парчета наменули; прво парче је кућанско, па положниково, па за путника и...не сећам се више.

(А тесто се месило са јајима или без?) Како са јајима? Слатко? Не. Cе месило са мајом, са квасизом, од брашна и воде, без јаја и без млека. А месила се и развила као нека погача, опет од теста и на ту погачу правило се као

\footnotetext{
${ }^{6}$ Јоргован Марков Јаворка. „Лебац је Божје лице“ (Обредни хлеб и жито код Поморишких Срба). Исходишта 1. Темишвар, 2015, 204.
} 
неке мумурице, то је била камара сас сеном па опет од теста као овце и краве и то је стојало настал на Бадње вече.

Да не заборавимо за чеснииу. Она се правила на први дан Божића рано изјутра. Тесто се теглило око астала, па се ове коре расечеду на парчади и ману да се суше. Онда се меће у плек и ређају се коре па самлевени ораси, шећер, суво грожђе, па се мало поспе с олајом и све тако редом до краја. (A леј се меће?) Како да не. Обавезно. Ако нађу тај леј деца ондак они га проду домаћину да остане леј у кућу.

ПЕЧКА: Рано ујутро месио се божићни колач, здравље, колачићи за коринђаше, звезде, месеи, птице. Колач је био подоста велики и округао окићен троструким плетеницама. Кад се испеко покривао би се уз молитву, па затим поставио на решето у које су зрневље и тако остајало на сто. $A$ могао се остављати и на тањир или салвет. Трећег дана Божића домаћин благодари Богу. Моли за здравље и реже унакрст и сече, па по један комад даје сваком члану породице. (Да ли домаћин реже колач са неким из куће?) Не, сам то ради. (А здравље?) Се месио од истог теста као и колач са млеком, округао као мағи колачић. (Је ли горња страна премажена медом?) Углавном не би се премазивала. Првог дана Божића се ломио и од юега би окусили сви чланови породице. (Да ли се још нешто месило?) Месила се душа, округла, па затим месец, суние, звезде, птице а месио се посебан колач са јајима и млеком и тај колач се носио кумовима. Тај колач се месио са млеком и јајима. (Ко је све ово јео?) Па, месец, звезде, сунце, тпице, давало се углавном деци. Оно што је преостало давало се животињама. Исто се овема давало и од јела што је остало од Бадње вечере.

(А чеснице да ли је било?) Има је и сад. (Како се спремала чесница?) На Бадњи дан рано, мешало се брашно, уље, вода, мало соли, шећера и месило се у обге. Ове су се растезале на танке лишће па се тако редом мећало y плех: кора се посула млевеним орајима и шећером па опет кора, да буде парни број кора. Негде се сакривао новчић а онај који га је нашао сматрао је да ће бити срећан. (Кад се чесница јела и како се делила?) Јела се првог дана Божића после ручка. Прво парче припало је домаћину, па осталим члановима породице и гостима, ако их је било.

КЕТФЕЉ: Ми смо у кући, на Бадњи дан, рано, веома рано подмесили квасац, а касније замесили Божићни велики колач и здравље. (Друго се више ништа није месило?) Моја покојна баба Даница месила је и овце са чобаном, звезду, месеи, све од теста. (Која је разлика између колача и здравља?) Па они су од истог теста замешени са квасием само што се колач китио плетеницом у три, имао је ружу, ондак се мећало и једно оре и струк од босиљка са ирвеном вуницом. Здравље кад се извадило из пећке се намазо озгоре са медом, да здравље буде слатко ко мед. Здравље се начело на вечеру. (Да ли се знао неки ред, кришке здравља ко је све јео?) Пре почетка вечере чита се молитва и ондак се прекрсти здравље и сече се. Први комад остане 
за кућу, ондак се оставља за путника намерника, за коринђаше и тако свако добије једно парче које мора да поје на вечеру.

Док је моја бака била жива ја сам по њеном казивању записао начин на који је она спремала чесницу. На први дан Божића замеси се смеса од брашна, соли, мало масти, једног јајета и воде. Замешено тесто остави се да се мало одмори па се после развије у танке коре. У плех намазан машћу или олајом стави се прва кора па се поспе самлевеним орајима и шећером, сувим грожђем па и исецканим смоквама. Упрска се течном машћу или олајом и слажу се у наставку коре. Наслажу се шест коре. Дабоме, обавезно се у чесницу сакрије леј којим се исплаћују марве које се оне године купују, ради среће и напретка. Горњи део чеснице премаже се медом.

Баба моје бабе (Даница Лазин рођена у деветнаестом веку) месила је чесницу коју је називала Христова погача од брашна, самлевених ораја, масти и шећера и воде по потреби у виду погаче. Ово је тесто развијала у тепсију, око два сантиметера дебљине, сечивом ножа нацртала коцке а у сваку коцку чашом зацртала круг и ставила да се испече. Док је још врела, извађена из пећке, премаже се медом и потом изреже свака коцка.

САРАВОЛА: Код нас у кући било је здравље округло, од обичног теста. Дабоме, пре вечере домаћица је кидала од тог здравља свима по једно парче. То си требо да појеш да би преко године био здрав. (А колача није било?) Био је, како не. Био је велики колач за кума. На други дан Божића ишло се код кумова и носио тај кумин колач. А правили су још и мали колачићи: јагањцуе, јасле све од теста. То је све било метуто настал. Ту је стојало.

Била је још и чесница. То смо као децуа највише волели. Слатка са орасима и унутра леј. Па кад нађеш тај леј нема веће радости.

Божићна слама - уношење Божића. У нашим Поморишким србским домаћинствима где још има и млађих укућана и данас се уноси слама. Не у оној количини у којој се раније уносила али буде у кући сламе. Данас, углавном испод стола ставе један завежљај сламе или сена, понеки клип кукуруза, посуду са зрневљем. Уношење сламе у кући означавало је оношење Божића. Слама у кући је сваког подсећала на Витлајемску пећину, у коју су биле смештене овце и где се Господ Христос родио. Мила Босић наводи да овај обичај „потиче из прахришћанских времена."7

ЧАНАД: Код нас у кућу, тата је, после вечере, доносио сламу. Кад је ушао отпевао је Рождество Твоје Христе Боже наш и простирао сламу по соби. Под астал је остављао више сламе и неколико клипова кукуруза. Сламу је стрвио и по столу и обавезно стављао новчаницу од 100. леја. Мама је све то покривала са стољььком. После овога, опет тата је бацао ораје

\footnotetext{
${ }^{7}$ М. Босић. . Божићни обичаји Срба у Војводини, 91
} 
по ћошковима собе, онако унакрст. Код нас је био обичај да слама остане у кући до у поноћи на други дан Божића. На светог Стевана није смело да се слама нађе у кући. Код нас, на трећи дан Божића, није било праћење Божића.

(А бадњак, да ли је постојао и да ли се уносио?) Не, код нас у Чанад ја не знам да је неко у кућу уносио бадњак. Сви су уносили сламу. То је бадњак. Ми сада у Цркви палимо бадњак.

ВАРЈАШ: (Да ли се у Варјашу зна за бадњак?) За бадњак...не, ми то нисмо имали. Код нас деда је, као најстарији, уносио Божић. Деда иде напред ди је камара са сламом и зове пилиће, пачиће, свиье, овце и само говори: пи,пи, пи, ли, ли, ли, мее, бее и тера и нас децу да то говоримо. А деца ко деца, кикоћу и смију се. Деда нас онда кори и оштро нам прети: Немојте се смијати. Оћете да побегне Божић? Деда носи сламе у врећу и свако од нас по мало у крило. На улазна врата у кућу деда куца и поздравља оне унутра: Добро вече. Честитамо бадюе вече. Да ли примате Божић. Мајка изнутра одговара: Примамо, примамо, уђите. Кад се уђе одмах се стрви слама по ичелој соби па и по осталим собама. Деца једва чеку са ве ваљу по слами. Домаћица бацуа ораје по ћошковима, деца се грабе да скупе орасе и онда неко старији чита Оченаш. (Да ли се и на столу посипа слама?) Јесте. Настал се рашири велика паорска врећа па слама и све се то покрије чаршавом. Кад је то готово настал се меће посуда са зеленим житом, тегла са зрневљем у које је пободена свећа. Исто се сад настал меће и Божићни велики колач и здравље.

НАЋФАЛА: (Да ли се у Наћфали зна за бадњак?) Ми и наши стари то нису знали. Сад се пали дрво у ирквену порту на вечерње. Код нас се уносила слама. Газда и деца иду за сламу и узпут вичу: пи,пи,пи, ли,ли, ли, и остале животиње. Сламу увију у врећу и кад стигну газда каже: Добро вече. Честитамо бадюи дан. А домаћииа пита. А ита нам донесете и газда и деца вичу: ено носимо Божић... Кад уђе у собу, обично у кујну, стрви сламу по изелој кујни, соби а домаћица баца ораси по ћошковима и крсти кућу. (Да ли стављате сламу и испод стољњака?) Дабоме. Меће се слама и ондак се покрије са чариовом. (А настал шта мећете?) Па меће се колач, здравље, флашица ракије, у ситанце бобице жита и кукуруза, свећу у чирак или у флашу са житом.

ПЕЧКА: (Како се код вас уноси Божић у кућу?) Уноси га домаћин који се прекрсти и помоли се Богу за добар напредак укућана као и целог домаћинства. (А шта домаћин уноси?) Уноси сламу, сено, кукуруз, жито. (И шта са овим ради?) Сламу простире по соби, а меће и испод стољюака. Испод стола оставља се кукуруз и жито. (На сто шта се ставља?) Колач и свећа. Свећа може да буде забодена у зелено жито које је на светог Николу посивено. 
КЕТФЕЉ: Пре вечере најстарији у кући, код нас деда, а ја сам га пратио, ишао је у шталу или шопру где је већ било спремно сламе и у кецељу доносио у кућу. Закуца на врата, прими потврдан одговор и тада ућемо. Уследи поздрав: Добро вече. Честитамо Бадюи дан. На питање ита доноси, деда одговара: носим Божић. Примите Божић? Свакако да је одговор: Да, примимо и одмах почиње да простире по соби онај нарамак сламе. Бака у неку стару посуду има зрневље преостале од положника и посипа по столу, исто и сламу и све то покрива стољњаком. Потом прекрсти собу орајима. На столу буде колач, здравље, тегла пуна зрневља у коју је забодена свећа са три гранчице од воћа из баште и све то увезано ирвеном вуницом.Од тог тренутка Божић је унесен у кућу и може да се вечера јер следе да дођу коринђаши.

САРАВОЛА: (Како се код вас уносио Божић у кућу? Је ли било бадњака?) Не, није се знало за бадюак. Сад палимо дрва у порту иркве. Код нас Божић се уносио тако: тата је ишао напред, деца иду за њим и пијучу. Узима сламу и враћа се а ми деца држимо се само за њега и пијучемо. Тата иде напред и баца сламу свугде и по штали и говори: Дај Боже да буде марви и кокошки, дај Боже. Кад је улазио у кућу мама је од њега примала сламу на пешкир и потом стрвила по соби, испод стољьака на столу. Код нас није се крстила соба орајима.

Бадњиданска вечера. Бадњи дан је последњи дан Божићњег поста па је и вечера била строго посна. Из свега онога што су моји казивачи говорили може се закључити да је бадњиданска вечера један од најважнијих елемената божићне традиције, јер је поредак захтевао да се тада, около бадњиданске вечерње трпезе окупе сви укућани. Домаћинства која су имала раднике, чобане, пастире било је обавезно да и ови присуствују на ову вечеру, ${ }^{8}$ за коју Мила Босић каже да “од почетка до краја је испуњена многим магијским радњама."9

ЧАНАД: За вечеру је обавезно била спремљена чорба од пасуља или од поврћа. Опет, специфично за Бадње вече, пошто се кувало посно јело, барио се иео кромпир са заприком и сос од ирног лука. То је, бар код нас у кући, била обавезна храна која се спремала за вечеру на Бадюи дан.

ВАРЈАШ: Обичај је био да најстарији, обично тата, пре вечере, окади кућу, јело и све укућане. Док је кадио говорио је гласно Оченаш а и ми остали са юиме. Ондак, остави ручку која се још пушила и цела соба и кућа су мирисале на тамјан. Тамјан је био природан, од витајеле, од оне смоле која се на кору стврдне и коју смо са ножићем гребали и скидали је.

\footnotetext{
${ }_{8}^{8}$ В. Чајкановић. Неколике примедбе уз српски ...,122.

${ }^{9}$ М. Босић. Божићни обичаји Срба..., 102.
} 
Ондак... дисам стигла...(Окади се цела кућа и потом шта се даље ради?) A, да. Ондак, пошто је јело настал, пали се свећа и тата реже здравље. Пре вечере смо свако добијали своју кришку од здравља и обавезно смо требали да то појемо. Онда смо почели да вечерамо. (Шта се од јела спремило?) Обавезно је био постан пасуљ, истучен, а одозгоре се прелио са запрагом од ирног лука. Било је и сувих илива. (А од разанаца да ли се нешто спремало?) Било је и тога. Разанц̧и онако широко сечени и дебљи са орасима и са маком. То је било најчешће. (Да ли се од тог јела остављало пострани или се све јело?) Свакако да је остајало, не много али је остајало. То се сутридан давало живини. А, да, сад сам се сетила. Пре вечере домаћицуа, мајка, а после сам ја то радила у кући мог свекра, од сваке врсте јела се узимало по мало и мећало у једну посебну посуду и то се давало живини.

НАЋФАЛА: За вечеру на Бадюи дан увек се спремао пасуљ. Кувала се посна чорба од пасуља, па густ пасуљ. Друга врста јела, коју смо јели на Бадњи дан су резанци измешени у кућу са маком и орасима. (А суве шљиве?) Било је и тога. Суве иљиве нису сви имали...Онако, мало надимљене па миришу на дим. Деца су волела суве шьиве. Биле су слатке. (А пре почетка вечере да ли се нешто радило?) Пре почетка?...Па да, најстарији је палио свећу, читао Оченаш и кадио с тамјаном. А могла је и мама да кади.

ПЕЧКА: (Шта се код вас спремало за бадњиданску вечеру и како је она протекла?) Настал је већ био постављен колач и свећа и онда је домаћиияа донела постан пасуљ скуван на води, без олаја, а спремало се и тесто са маком. (Да ли се од те хране узимало по мало и остављало у...?) Да, обавезно се од сваке врсте јела одвојило по мало, јако мало, и то се други дан давало кокошкама или марвама. (Да ли се свећа гасила обично или се то радило на посебан начин?) Није постојао никакав посебан начин, једноставно се угасила. Требало је да се у том моменту изговори молитва. (Која молитва?) Ону коју је најбоље знао.

КЕТФЕЉ: Баба је у једну стару каиику узимала из шпорета жеравице, мећала две три бобице природног тамјана,и кадила собу, јело и све нас. Као најмлађи ја сам увек морао да говорим Оченаш, она је завршавала да кади а деда је палио свећу која је била пободена у дунстфлашу у коју је било зрње од жита и кукуруза. Около свеће су увек биле забодене три танке гранчице од воћа која су расла у башту или у авлију. На столу, на стољььку, је био постављен божићни колач и здравље. Вечера је била посна. Након поста ова спремљена посна храна била је најукуснија од свих осталих. Јело се, обавезно супа од пасуља, густ истучен пасуљ са издинстаним луком, а спремале се још и домаће резанице са маком или орасима. Обавезно се начињало здравље и јело на вечеру. Код нас у кући домаћин је најпре крстио доюу страну здравља и сечивом ножа три пута урезао крст говорећи сваки пут: У име Оцуа и Сина и Светога Духа. Сече једно мало парче, кућанско, а 
које се заједно са парчетом чеснице чува три дана празника и онда подели марви да то поједу. Друго парче здравља намењено је покојним родитељима и потом следе живи чланови породице и свако прими по једно парче.

Памтим да је бака пре вечере узимала по мало од сваке врсте хране и стављала у једну стару мању посуду. Ово је остављала на хладно место и потом давала кокошкама и свињама.

После вечере гаси се свећа, пере се посуђе и сво посуђе и прибор за јело враћа се на сто и ту стоји у дане празника, све док се Божић не почисти из куће, на трећи дан.

Занимљив је начин на који се у појединим србским кућама у Кетфељу гасила божићна свећа. У породици Радивоја Маркова домаћин је, на крај вечере узимао свећу и док је још горела окретао је са пламеном на доле и забадао у зрневље из тегле. Свећа се, на тај начин гасила, а за истопљени восак или парафин залепе се зрнца жита и кукуруза. Ова су се зрна бројала и у зависности од којих је зрневља било више, сматрало се да ће оне године она житарица најбоље родити.

САРАВОЛА: Као и у осталим местима и у Сараволу, најглавније јело била је чорба од пасуља, па густ пасуљ, као и резанци са маком. Домаћица је здравље кидала руком и делила укућанима. Такође, казивач се присетио да у њиховом дому прибор за јело, то јест само кашике (виљушаке и ножеви нису били изнешени), као и да посуђе није стајало на столу, већ поређано на поду и оданде је свако узимао оно што му је требало. Највероватније да су у давнини укућани вечерали седећи на поду, на слами, а не около стола.

Први дан Божића. Од казивача из Печке смо сазнали да на први дан Божића домаћин и остали укућани су се умивали и нову воду, свеже донешену, а да у ову нису ништа стављали.

У Варјашу укућани су воду са којом је требало да се умију стављали мало жеравице, док је у Кетфељу домаћица стављала новчиће или леј који ће касније да сакрије у чесницу. Овај обичај се појављује и код Срба у Војводини, а наводи га и Мила Босић. ${ }^{10}$

Божићни ручак је био свечан и обилат. Свако је једва дочекао да се постави трпеза и почне ручак, поготово они који су постили, који су се причестили и једва су чекали да једу јачу храну. Оно што је својствено за сва домаћинства и за сва наша села, за побожне породице јесте: осењивање себе крсним знаком, паљење свеће, кађење трпезе, куће и укућана, резање божићног колача, евентуално групно коринђање. За ручак првог дана Божића спремала се следећа јела:

ЧАНАД: супа, а као божићни специјалитет пуњена цела патка, печеница од шунке или вратна крменадла, кремпита и само за Божић спремљена торта са орасима.

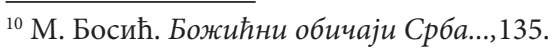


ВАРЈАШ: кува се живинска супа, римфлајш (сос и кромпир), сос од парадајза, печено месо и кобасица. Овде божићни колач је секла домаћица, деца га ломе и гледају којим од њих је припала ружа. Занимљиво је, да ,по казивању моје казивачице, после вечере поново бацају ораје.

НАЋФАЛА: - служила се кокошја супа, свињско печено месо. Месо од кокошке није се јело да кокошке не би чепркале по кући (људи да не „чепркају” у кућу), а кости се бацају у ватру да не би керови хватали и јели живину. Домаћице су спремале савијаче са маком, рогачом, сиром.

ПЕЧКА: На божићну трпезу домаћице су износиле живинску супу, кувано месо са кромпиром и зеленом, сос од парадајза као и свињско и живинско печење. Данас се исто служи. Раније, домаћице су спремале штрудле са маком и орасима, а данас се служи торта. Божићни колач домаћин је резао трећег дана и свима присутнима поделио по парче. Још један занимљив детаљ сам сазнао од мог казивача: У овим крајевима, за Божић, се обавезно стављао на столу поред колача зелено жито које се сејало у земљи на светог Николу. У средини овога је била запаљена свећа или кандило. Поред ове посуде са житом, поред колача, била је постављена још једна посуда у прозор према улищи. Поред юе су се около поређале овчице направљене од вуне или фате.

САРАВОЛ: служена је живинска супа, црвен сос, куван кромпир и живинско месо, печено свинско месо, свинска печена кобасица и дунст. Домаћице су спремале и божићну торту са медом.

3.

Примећује се као нека једнообразност код Поморишких Срба што се спремања извесних врста хране тиче. Оно што чини разлику можда се може објаснити и обичајима у појединим породицама специфичне само за извесне породице. Постоји, међутим, заједничка нит која спаја све ове породице а то је врста хране која се спрема и поставља на трпезу Бадње вечери и првог дана Божића. У свим кућама служи се пасуљ (на разне начине), а резанци са маком и орајима као главно јело.

Изостанак бадњака и уношење сламе у кућу, као и извођење ономатопеја старије особе која доноси сламу-Божић, па и деца која исте ономатопеје користе, јесте још један заједнички елеменат, именитељ, духовна нит која спаја и уједињује србске породице из Поморишја.

Положник је још један заједнички елеменат који спаја све поморишке Србе међусобно, а такође и са Србима из Баната и Војводине.

Обредни божићни хлебови су, такође, су заједнички елемент који сједињује све Србе са територије данашње Румуније, а и шире у Матици. 
Иако се могло идентификовати неколико заједничких елемената који попут невидљиве жиле куцавице спајају и надахњују дух овдашњих Срба. Ипак се уочава постепено слабљење овог ујединитељног Духа, свести и савести нас Срба са ових територија. Све до 1989. године србска заједница у Румунији, не само да је била многољуднија него данас, била је и много компактнија и уједињенија. Жељни и жедни свога, србског, Срби су долазили у своје православне храмове где су на свом матерњем језику међусобно општили. Љубоморно смо чували веру, језик, обичаје. И ако највећи део нас нисмо познавали смисао начина на који смо славили било неку светковину, било да смо упражњавали неки верско-народни обичај, пазили смо да то најверније очувамо и присвојимо као део себе, нашег идентитета. Политичка забрана слободног кретања протеклог режима утврдила нас је у своме, идентификовала нас у многоетничком свету, дала нам легитимитет. Ипак, некима од нас, најлакше је било да прстом покажемо на режим који нам је ускраћиво и забрањивао јавна исповедања, да се ламентујемо, да осуђујемо све оне са власти како нам не дају да идемо у цркву, да славимо, и да на тај начин пред собом и пред светом оправдамо нашу личну комотност, страх, маловерје, духовну млакост, све веће определење за овосветско, и да, на тај начин, у времену, све више занемаримо духовност и обичаје.

Велики део нашег живља је упркос свим притисцима и забранама протеклог режима, у својим породицама, домовома, домаћинствима редовно славио славу, верске празнике пропраћене свим обичајима који су везани за дотичан празник, одлазио у цркву, постио и причешћивао.

Наклоњени смо, углавном, да због већ изгубљених обичаја кривицу приписујемо комунистичким забранама. Свакако, има смисла ова чињеница. Међутим, употпуности противно конзервацији, очувању и упражњавању старинских црквено-народних обичаја има садашње демократско, слободоумно, уређење у духу новосветског поредка, а који омаловажава верско-национално моралне вредности.

Примећујемо да помоћу телевизијских реклама, филмова, па и онога што се у данашњем друштву дешава, наши умови и умови наше деце, начин размишљања, сагледавања на духовно-моралне вредности, на свет, на породичну традицију, изопачује се, искривљује, блати се, испоцењује. За све што је за нас до јуче било вредно, свето и племенито, за све то, новосветски поредак проналази замену, сурогате. Уместо Новорођеног Богића појављује се космати старац из скандинавске митологије а који у ствари треба да буде оличење светог Николе. Уместо сламе по соби имамо бљештава светла лампица и светлећу јелку, сада вештачку. Уместо скромне посне бадњиданске вечере имамо разне азијске специјалитете. Уместо наших коринђања из свих звучника нас бомбардују англо-саксонске и протестантске песме. Пошто је то одраз еманципованог и напредног западног друштва, ми православни народи који смо „и даље” остали „жигосани” комунистичким схватањем, у 
ходу вршимо измену, прихватајући ове изазове. Наша деца се крећу, живе у таквом модерном друштву, одишу овај хедонистички дух и дах и неминовно занемарују своје старе вредности, црквено-народне обичаје а уз ове и језик и веру, култ и културу.

Све ово као и садашњи ритам живота, полако али сигурно, удаљује нас од свега што смо наследили, од свега нашег србског традиционалног.

\title{
Литература и извори
}

Теренска грађа. 2019: Наћфала, Варјаш, Саравола, Печка, Кетфељ.

Босић: М. Босић, Божићни обичаји Срба у Војводини, Вук Караџић - Београд,

Етнографски музеј - Београд, Војвођаљнски музеј - Нови Сад.

Чајкановић, 1994: В. Чајкановић „Неколике примедбе уз српски Бадњи дан и Божић”, у: Студије из Српске религије и фолклора 1910-1924, Београд 1994.

Ивановић Баришић, 2019: М. Ивановић Баришић, „Божић код Срба у Румунији Краљевац и Чанад”. Исходита 5, 2019, 129-144.

Јоргован Марков, 2015: Јоргован Марков, Ј., „Лебац је Божје лице (Обредни хлеб и жито код Поморишких Срба)", Исходишта 1. Темишвар, 2015.

Blagoje Čobotin

\section{ELEMENTS OF THE SERBIAN CHRISTMAS RITUALS FROM THE SERBS LIVING ON THE SHORES OF MURES RIVER}

\author{
Summary
}

This study is the result of field research that we have conducted in some of the villages situated on the shores of Mures River, where a Serbian community still exists and therefore I managed to identify some important people that know the customs and popular traditions of the Church. The content of the article presents the elements of the Christmas rituals, those that are still retained and used, as well as those rituals from the past that have been lost over time and are no longer practiced today. We have also tried to identify the causes that contributed to the forgetting or loss of these Christmas habits and rituals of the Serbian community living on the shores of Mures River.

Key words: The Serbs living on the shores of Mures River, Christmas, badniac, Christmas carol, Christmas cake. 